\title{
Bővülő állatkert? - Az Európai Unió Bíróságának ítéletei a szlovák civil szervezetek környezeti engedélyezési eljárásokba való bevonásáról
}

\author{
aarhusi követelmények - közösségi részvétel - az igazságszolgáltatáshoz \\ való hozzáférés - a tagállamok eljárási autonómiája
}

Az ENSZ keretein belül elfogadott Aarhusi Egyezmény ${ }^{1}$ (a továbbiakban: Egyezmény) a környezeti ügyekben az információhoz való hozzáférésről, a nyilvánosságnak a döntéshozatalban történő részvételéröl és az igazságszolgáltatáshoz való jog biztosításáról rendelkezik. Vegyes egyezményként olyan nemzetközi megállapodás, amelynek a tagállamok mellett az Európai Unió (akkor Európai Közösség) is részes fele, így annak követelményei az Unió jogának részét képezik. Az utóbbi években az Európai Unió Bírósága (a továbbiakban: EUB) aktivista felfogást követve több döntésében is kinyilvánította, hogy az Egyezmény eljárási követelményeinek széles körű érvényesülését a tagállami bíróságoknak biztosítaniuk kell. Szlovákia különösen érintett az EUB megállapításai révén. A „szlovák barnamedvék” (C-240/09. sz.) ügyben hozott ítéletével ${ }^{2}$ az EUB nem ismerte ugyan el, hogy a civil szervezetek közvetlenül hivatkozhatnának az Egyezmény azon rendelkezésére, amely elvárja az igazságszolgáltatáshoz való hozzáférés tág értelemben vett biztosítását. Ugyanakkor a tagállami bíróságok egyezménykonform jogértelmezési kötelezettségét általános jelleggel fektette le ebben az ügyben a luxemburgi esetjog, ami több, e régióbeli tagállam jogalkalmazására is kihatott. Ezt követően pedig a „szlovák szarvasok” (C-243/15. sz.) ügyben (amely a szakirodalomban gyakran LZ II. ügyként, illetve szlovák barnamedvék II. ügyként is szerepel) hozott legújabb ítéletében ${ }^{3}$ az EUB ismét az eddigi (kiterjesztő) megközelítését követte. Eszerint ugyanis az igazságszolgáltatáshoz való széles körü hozzáférés aarhusi követelménye akkor teljesül, ha a

* Dr. Szegedi László egyetemi adjunktus, Nemzeti Közszolgálati Egyetem Európai Köz- és Magánjogi Tanszék, Budapest. E-mail: Szegedi.Laszlo@uni-nke.hu.

1 A környezeti ügyekben az információhoz való hozzáférésröl, a nyilvánosságnak a döntéshozatalban történő részvételéről és az igazságszolgáltatáshoz való jog biztosításáról szóló, Aarhusban, 1998. június 25-én elfogadott egyezmény.

2 C-240/09. sz., Lesoochranárske zoskupenie VLK kontra Ministerstvo životného prostredia Slovenskej republiky (Szlovák barnamedvék) ügyben 2011. március 8-án hozott ítélet (ECLI:EU:C:2011:125).

3 C-243/15. sz., Lesoochranárske zoskupenie VLK kontra Obvodný úrad Trenčín (Szlovák szarvasok) ügyben 2016. november 8-án hozott ítélet (ECLI:EU:C:2016:838), amelyet szakirodalmi álásfoglalások a szlovák medvék II vagy LZ II megjelöléssel is illetnek, utalva a két vizsgált ügy szoros összefüggésére. 
fellépni kívánó civil szervezetek ügyféli minőségéről azelőtt születik jogerős döntés, hogy az alapeljárás jogerősen lezárulna. A címben említett tagállami eljárási autonómia bár elméletileg máig érvényesül, az EUB aarhusi ítéletei egyértelműen jelzik, hogy a luxemburgi esetjog azt egyre inkább visszaszorítja. E gyakorlat tükrében persze kérdéses, hogy az említett uniós bírósági gyakorlat csak a környezetvédelmi ágazatra vonatkozik-e, vagy egyre inkább általános követelményként kell-e ezekre a tagállami bírónak tekintenie. Célom az Egyezmény aláírásának 20. évfordulóján annak bemutatása, hogy ez az aktivista hozzáállás milyen típusú ügyekben merült fel egy olyan szomszédos államban, ahol az EUB több esetben is álást foglalt már az aarhusi követelmények értelmezését illetően, valamint annak vizsgálata, hogy ezek az esetjogi megállapítások mennyiben kaphattak határokon átívelő jelentőséget. Ugyanis a korábbi ítélet több régióbeli tagállam ítélkezésében is hivatkozási alapként tűnt fel, így ezen ítéletek Magyarországon is külön figyelemre tarthatnak számot.

\section{Az Aarhusi Egyezmény felemás átültetése}

Az Egyezmény belső szerkezeti egységeit három olyan pillér adja, amely egyben az egyes eljárási jogosultságokat is felöleli. Az Egyezmény első pillére a környezeti ügyekben az információhoz való hozzáférés, a második a nyilvánosságnak a döntéshozatalban történő részvétele, végül a harmadik az igazságszolgáltatáshoz való jog biztosítása és az ahhoz való hozzáférés. A jelzett, szlovák vonatkozású döntések közvetlenül mind a harmadik pillérhez, az igazságszolgáltatáshoz való hozzáféréshez kapcsolódnak.

Amint már említettem, vegyes egyezményröl van szó, amelynek a tagállamok mellett az Európai Unió is részes fele. ${ }^{4} \mathrm{~A}$ benne foglalt követelmények átültetése megtörtént közösségi irányelvekben ${ }^{5}$ is. Ám az átültető 2003/35/EK irányelv csak a környezeti hatásvizsgálati, valamint a környezetszennyezés integrált megelőzésére és csökkentésére irányuló irányelvek módosításával, az azok által szabályozott területeken várja el, hogy biztosítsák az érintett nyilvánosság részvételét, valamint az igazságszolgáltatáshoz való hozzáférését. ${ }^{6} \mathrm{E}$ máig problémás, felemás átültetés

4 A Tanács 2005/370/EK határozatát (2005. február 17.) a környezeti ügyekben az információhoz való hozzáférésről, a nyilvánosságnak a döntéshozatalban történő részvételéről és az igazságszolgáltatáshoz való jog biztosításáról szóló egyezménynek az Európai Közösség nevében való megkötéséröl, HL L 124, 2005. 05. 17., 1-3.

5 Az Európai Parlament és a Tanács 2003/4/EK irányelve (2003. január 28.) a környezeti információkhoz való nyilvános hozzáférésröl és a 90/313/EGK irányelv hatályon kívül helyezéséröl, HL L 041, magyar különkiadás fejezet 15 kötet 007 o. 375-381. A 2003/35/EK irányelv a 85/337/EGK (környezeti hatásvizsgálati) és a 96/61/EK tanácsi (a környezetszennyezés integrált megelőzésére és csökkentésére irányuló) irányelv módosításával csak az ezek által szabályozott területeken várja el a nyilvánosság részvételének, valamint az igazságszolgáltatáshoz való hozzáférésnek a biztosítását. Magyar különkiadás fejezet 15 kötet 007 o. 466-473.

6 A 2003/35/EK irányelv által módosított irányelvek követelményeit pedig szinte szó szerint vette át a környezeti hatásvizsgálatról szóló 2011/92/EU irányelv 11. cikke és az ipari kibocsátásokról szóló 2010/75/EU irányelv 25. cikke, bár az eljárási jogok biztosításának alkalmazási körét módosította. 
révén bár megtörtént az Egyezmény 9. cikk (2) bekezdésének átültetése, de ez gyakorlatilag elmaradt a szélesebb körü követelményeket lefektető, 9. cikk (3) bekezdés esetén.

Az Egyezmény 9. cikk (2) bekezdése, ${ }^{7}$ illetve az azt átültető irányelvi rendelkezések az Egyezmény döntéshozatali pillére szerinti eljárásban meghozott döntések megtámadhatóságának biztosítását várják el a tagállamoktól. Következésképpen az eljárási értelemben vett alanyi jogok sérelme szolgálhat elsődleges hivatkozási alapként az érintett nyilvánosság számára. ${ }^{8}$ Ugyanakkor az uniós jogalkotó máig nem vette át az Aarhusi Egyezmény 9. cikk (3) bekezdését. ${ }^{9}$ Ennek kapcsán külön irányelvtervezet ${ }^{10}$ is született, amelyet utóbb a Bizottság hivatalosan visszavont ${ }^{11}$ majd a problémakört egy 2017-es közleményben elemezte. ${ }^{12}$ A 9. cikk (3) bekezdés jelentősége abból fakad, hogy szélesebb körben várja el a hozzáférés biztosítását, mint a 9. cikk (2) bekezdése. A megtámadás ebben az esetben a hatóságok mellett a magánszemélyek lépései ellen is irányulhat, valamint a lépésekre és azok meghozatalának elmaradására, vagyis a mulasztásokra is kiterjed. Emellett a döntő tényező, hogy e bekezdés alapján hivatkozási alapként nem a vonatkozó eljárási követelmények, hanem általában véve a nemzeti környezetvédelmi szabályozás megsértése jelenik meg.

7 Valamennyi Fél, nemzeti jogszabályainak keretein belül, biztosítja az érintett nyilvánosság azon tagjai számára, akik

a) kelló érdekeltséggel bírnak a döntésben, vagy alternatívan,

b) jogaik sérülését állítják, amennyiben a Fél közigazgatási eljárási törvénye ennek fennállását előfeltételként szabja a felülvizsgálati eljárás hozzáférhetőségét bíróság és/vagy más, a jogszabályok által kijelölt független és pártatlan testület elött, hogy megtámadják bármely döntés, intézkedés vagy mulasztás anyagi vagy eljárási törvényességét, amely ütközik a 6. cikk rendelkezéseivel [...].

8 Az átültető 2011/92/EU irányelv 11. cikke és 2010/75/EU irányelve 25. cikke szerint a tagállamok biztosítják, hogy a vonatkozó nemzeti jogrendszerükkel összhangban az érintett nyilvánosság azon tagjainak, akik:

a) kellő mértékben érdekeltek; vagy

b) jogsérelemre hivatkoznak, amennyiben a tagállam közigazgatási eljárásjoga ezt előfeltételként írja elő, a bíróság vagy a törvény értelmében létrehozott, más független és pártatlan testület elött felülvizsgálati eljáráshoz legyen joguk a határozatok, jogi aktusok és mulasztások anyagi vagy eljárási jogszerűségének kifogásolása céljából ezen irányelvnek a nyilvánosság részvételére vonatkozó rendelkezéseire is figyelemmel.

9 9. cikk „(3) A fenti 1. és 2. bekezdésben tárgyalt felülvizsgálati eljárások szabályainak csorbítása nélkül valamennyi Fél biztosítja, hogy a nyilvánosság azon tagjai számára, akik a nemzeti jogrendszerben lefektetett kritériumoknak, amennyiben vannak ilyenek, megfelelnek, a közigazgatási és bírói eljárásokhoz való hozzáférés biztositott legyen, hogy megtámadhassák magánszemélyek és hatóságok olyan lépéseit és mulasztásait, amelyek ellentmondanak a környezetre vonatkozó nemzeti jog rendelkezéseinek."

10 Az Európai Bizottság COM(2003)624. sz. irányelvtervezete a környezeti ügyekben az igazságszolgáltatáshoz való hozzáférésröl.

11 A harmadik pillérre vonatkozó irányelv szükségességéről lásd PÁnovıcs Attila: Az Aarhusi Egyezmény és az Európai Unió. Publikon, 2015, 212-221.

12012 Az Európai Bizottság COM(2017)2616. sz. közleménye a környezeti ügyekben az igazságszolgáltatáshoz való hozzáférésről. 


\section{Az uniós és a tagállami eljárásjogi követelmények összeütközése}

\subsection{A civil szervezetek fellépési keretei a szlovák jog szerint}

A Szlovák Köztársaság 1990-es évek elején elfogadott alkotmányának „Alapvető Jogok és Szabadságjogok” címú része rendelkezik a jogorvoslati jogokról, amely a civil szervezetek fellépési lehetőségét érinti. „Ha törvény másként nem rendelkezik, bírósághoz fordulhat az, aki azt állítja, hogy jogait a közigazgatási szerv határozata sértette, hogy a bíróság az ilyen határozat törvényességét megvizsgálja." ${ }^{13}$ A bírói szervezetrendszer tekintetében a szlovák alkotmány csak annyit tartalmaz, hogy a bíróságok felülvizsgálják a közigazgatási határozatok törvényességét, valamint hogy a bíróságok rendszerét a Szlovák Köztársaság Legfelsőbb Bírósága és a többi bíróság alkotja. ${ }^{14}$ Külön bíróságokként közigazgatási bíróságokkal nem találkozhatunk a bírósági szervezetrendszer egyik szintjén sem, ahogyan külön közigazgatási perrendtartással sem.

A közigazgatási határozatok bírósági felülvizsgálatának szabályait a szocialista jogfejlődés maradványaként, a polgári perrendtartásról szóló törvény tartalmazza. ${ }^{15}$ Ez egyértelmüen utal arra, hogy a felülvizsgálat megindításának feltétele a szubjektív jogsérelem léte, illetve annak állítása. ${ }^{16}$

A régióbeli szabályozásokhoz hasonló megközelítést alkalmaztak és alkalmaznak Szlovákiában. Így a keresetindítás feltétele a hatósági eljárásban való részvétel, arra hivatkozással, hogy a közigazgatási szerv eljárása vagy meghozott döntése (a felperes saját) jogát érintette. ${ }^{17} \mathrm{~A}$ szlovák közigazgatási eljárási törvény félként ismeri el azt, akinek joga, jogos érdeke, illetve kötelezettsége az eljárás tárgyát képezi; aki közvetlenül érdekelt az eljárásban vagy akinek jogát, jogilag védett érdekét, kötelezettségét érinti az eljárás. ${ }^{18}$ Ugyanakkor a félként való elismerés feltétele a közvetlen, személyes, legitim érdek megléte, illetve az, hogy a döntés vagy a hatóság eljárása a fél (saját) jogi helyzetére vonatkozzon. ${ }^{19}$ Ágazati törvények biztosíthatják a civil szervezetek részvételi lehetőségét is, de nem mindegy, hogy milyen minőségben. ${ }^{20}$

A jogalkotó 2007-es döntéseivel lerontotta a helyi szervezetek és környezetvédelmi civil szervezetek eljárási pozícióját, amelyek az általános eljárási kódex terminológiája szerinti fél helyett pusztán résztvevőként nyertek elismerést, akik automatikusan nem bírtak jogorvoslati joggal. ${ }^{21} \mathrm{E}$ szűkített eljárási pozíció, illetve annak

13 A Szlovák Köztársaság Alkotmányának 46. cikk (2) bekezdése. (Szlovák Köztársaság Törvénytára: 460/1992. szám, kelt: 1992. szeptember 1.)

14 A Szlovák Köztársaság Alkotmányának 142. cikk (1) bekezdése; a 143. cikk (1) bekezdése.

15 A polgári perrendtartásról szóló 1963. évi 99. törvény V. része.

16 A polgári perrendtartásról szóló 1963. évi 99. törvény 247. cikk (1) bekezdése.

17 Summary Report on the Inventory of EU Member States - Measures on Access to Justice in Environmental Matters. Country Report for the Czech Republic. Milieu Ltd., 2007, 15. http://ec.europa.eu/environment/ aarhus/study_access.htm (2018.03.15.).

18 A közigazgatási eljárásról szóló 1967. évi 71. törvény 14. cikk (1) bekezdése.

19 A közigazgatási eljárásról szóló 1967. évi 71. törvény 14. cikk (1) bekezdése.

20 A közigazgatási eljárásról szóló 1967. évi 71. törvény 14. cikk (2) bekezdése.

21 A közigazgatási eljárásról szóló 1967. évi 71. törvény 15a. cikke. 
eltérése a hatósági eljárás ügyfeléhez képest lett az EUB szlovák vonatkozású ítéletének tárgya is.

\subsection{A szlovák barnamedvék ügyében hozott luxemburgi ítélet}

\subsubsection{Az ítéleti tényállás}

A szlovák barnamedvék ügyében hozott ítélet kiindulópontját egy előzetes döntéshozatali kérelem jelentette. Az alapügyben egy környezetvédelmi egyesület kérte, hogy „félként” részt vehessen az élőhelyvédelmi irányelv hatálya alá tartozó fajok, mint a barnamedve védelmére vonatkozó szabályoktól való eltérés engedélyezésére, védett természeti területekhez való hozzáférésre vagy vegyi anyagok ilyen területeken való használatára vonatkozó közigazgatási eljárásban. A szlovák természetvédelmi törvény mint ágazati törvény alapján az egyesületek „résztvevőként" jogosultak arra, hogy tájékoztassák őket a természet és a táj védelmével kapcsolatos, valamennyi folyamatban lévő közigazgatási eljárásról. Az ágazati rendelkezéseket érintő 2007-es módosítás után az egyesületet érdekeltként továbbra is tájékoztatták az olyan eljárásokról, amelyek tárgya a környezetet érintette, és adott fajok és területek védelmétől való eltérésre irányultak. ${ }^{22}$ Ám keresetindítási joggal már nem rendelkezett. 2008-ban az egyesületet arról tájékoztatták, hogy különböző vadászegyesületek és más személyek kezdeményezésére több közigazgatási eljárás indult a barnamedve és más fajok védelmére vonatkozó szabályoktól való eltérés engedélyezésére.

Az egyesület arra irányuló kérelmét, hogy a kapcsolódó engedélyezési eljárásokban ügyféli minőségét ismerjék el, a szlovák környezetvédelmi minisztérium elutasította, ahogyan az elutasító határozat ellen benyújtott közigazgatási jogorvoslati kérelmet is. ${ }^{23} \mathrm{Az}$ egyesület keresetet nyújtott be e két határozat ellen, amelyben többek között az Aarhusi Egyezmény 9. cikkének (3) bekezdésére hivatkozott, hogy a megindult közigazgatási eljárásokban féli minőségét alátámassza. Az elmaradt uniós átültetés ellenére óhatatlanul felmerült, hogy az Egyezmény hivatkozott rendelkezésének van-e közvetlen hatálya. Miután az ügyben eljárt regionális bíróság elutasította az egyesület érvelését, az ügy a Szlovák Köztársaság Legfelsőbb Bírósága elé jutott, amely döntött az előzetes döntéshozatal iránti kérelem előterjesztéséről. ${ }^{24}$

\subsubsection{Az ítélet legfontosabb megállapításai}

Egy vegyes egyezmény és konkrétan az Egyezmény adott rendelkezésének közvetlen hatályát az EUB a már kialakult gyakorlat szerint vizsgálja meg. Az Egyezmény

22 A 2007. évi 554. törvény módosította a természet és a táj védelméről szóló 2002. évi 543. törvényt 2007. december 1-i hatállyal.

23 C-240/09. sz., szlovák barnamedvék ügyben hozott ítélet 21. pont.

24 C-240/09. sz., szlovák barnamedvék ügyben hozott ítélet 23. pont. 
egészét illetően egyértelmű az EUB álláspontja, amely az Aarhusi Egyezményt azért tartja az uniós jogrend szerves részének, mert a Közösség is aláírta, majd pedig a 2005/370 határozattal jóváhagyta az Aarhusi Egyezményt. ${ }^{25}$ A vizsgálat második lépését jelentette a konkrét rendelkezés közvetlen hatályát illetően az EUB hatáskörének vizsgálata. Saját esetjoga alapján ilyen rendelkezések közvetlen hatályáról abban az esetben dönthet az EUB, ha az Unió már élt a rendelkezés szabályozási tárgyában jogalkotási hatáskörével. ${ }^{26}$ Ellenkező esetben ugyanis a tagállami bíró joga arról dönteni, hogy magánszemélyek hivatkozhatnak-e a vegyes egyezmény említett rendelkezéseire.

Az EUB akként foglalt állást, hogy az EU már alkotott rendelkezéseket az Aarhusi Egyezmény 9. cikke (3) bekezdésének hatálya alá tartozó területen, így az uniós jogot kell alkalmazni, és az EUB dönt a közvetlen hatály kérdéséről. Érvelése szerint „az olyan speciális kérdés, amelyet az Unió még nem szabályozott, az uniós jog hatálya alá tartozik, ha e kérdést az Unió és a tagállamai által kötött megállapodásban szabályozták, és e kérdés olyan területre vonatkozik, amely nagyrészt az uniós jog hatálya alá tartozik". Utóbbi feltételt azáltal látta biztosítottnak az EUB, hogy az élőhelyirányelv által szigorúan védett faj a barnamedve. ${ }^{27} \mathrm{Az}$ érvelés több tekintetben is kritizálható, mint látni fogjuk, ugyanakkor ez az aktivista uniós bírósági szerepfelfogásnak is egy tetten érhető példája.

Továbblépve a hatásköri kérdésen, nem ismerte el viszont az EUB az Aarhusi Egyezmény 9. cikk (3) bekezdésének a közvetlen hatályát. Úgy ítélte meg, hogy az nem tartalmaz egyetlen, a magánszemélyek jogi helyzetét közvetlenül szabályozó, világos és pontosan meghatározott kötelezettséget, amelynek végrehajtása vagy hatálya semmilyen későbbi aktusnak nincs alárendelve. ${ }^{28}$ Ugyanakkor abban a tekintetben egyértelmü az EUB érvelése, hogy megfelelő uniós szabályok hiányában a tagállamok kötelezettsége az egyezményi követelményeknek megfelelően a részvételi jogok hatékony védelme, vagyis az eljárási szabályok meghatározása „a nyilvánosság azon tagjai” számára, „akik a nemzeti jogban meghatározott kritériumoknak [...] megfelelnek".

Végül az EUB a nemzeti bíróságoktól megköveteli a nemzeti eljárási szabályok egyezménykonform, ebből fakadóan kiterjesztő értelmezését, amely magában foglalja az uniós jog által biztosított jogok hatékony bírói védelmét - függetlenül attól, hogy a 9. cikk (3) bekezdésének közvetlen átültetése az uniós jogrendbe nem történt meg. ${ }^{29}$

25 C-240/09. sz., szlovák barnamedvék ügyben hozott ítélet 30. pont.

26 C-300/98. és C-392/98. sz., Parfums Christian Dior SA kontra TUK Consultancy BV és Assco Gerüste GmbH és Rob van Dijk kontra Wilhelm Layher GmbH \& Co. KG és Layher BV ügyben 2000. december 14-i ítélet (ECLI:EU:C:2000:688), 48. pont; C-431/05. sz., Merck Genéricos - Produtos Farmacêuticos Lda kontra Merck \& Co. Inc. és Merck Sharp \& Dohme Lda ügyben 2011. szeptember 11-i ítélet (ECLI:EU:C:2007:496) 34-38. pontja.

27 C-243/15. sz., szlovák barnamedvék ügyben hozott ítélet 36., 37. pont.

28 C-240/09. sz., szlovák barnamedvék ügyben hozott ítélet 45. pont.

29 C-240/09. sz., szlovák barnamedvék ügyben hozott ítélet 47-52. pontjai. 


\subsubsection{Az ítéleti érvelés kritikája}

Az ítélet komoly elörelépést tett, s emellett pedig talán a legnagyobb nemzetközi visszhangra tett szert az „aarhusi ügyek” sorában.

Az ítéletbeli értékelés középpontjában az uniós jogalkotási hatáskör kimerítésének dilemmája állt. Az Egyezmény 9. cikk (3) bekezdése esetén a jogalkotási jogkör kimerítésének elmaradását s egyúttal az EUB hatáskörének hiányát támasztja alá az uniós csatlakozási határozat melléklete, amelyre egyébként az EUB is hivatkozott. ${ }^{30} \mathrm{Az}$ EUB idézi az említett határozat azon részét, amely szerint a tagállamok „felelösek maradnak mindaddig a 9. cikk (3) bekezdése szerinti kötelezettségek végrehajtásáért, amíg a Közösség, az EK-Szerződés alapján meglévő hatáskörét gyakorolva, el nem fogad közösségi jogszabályokat azon kötelezettségek teljesítésének szabályozásáról”. Nehezen lehetne ezt a kitételt akként értékelni, hogy eljárásjogi szempontból megtörtént a jogalkotási jogkör kimerítése. ${ }^{31}$

A barnamedvék védelme alapvetően a természetvédelmi anyagi jogi szabályok körébe sorolható, ami ugyancsak a jogkör kimerítésének hiányát támasztja alá. A fötanácsnoki indítvány is akként foglalt állást, hogy egy védett faj, mint a barnamedve, szereplése az élőhelyvédelmi irányelvben, túlságosan „rendszertelen és önkényes” hivatkozás lenne annak eldöntéséhez, hogy az uniós vagy a tagállami bíróság jogosult-e az Egyezmény értelmezésére. ${ }^{32}$

Ugyanakkor a környezetvédelemben az EUB gyakorlata megengedőbb, hiszen találunk arra is példát - a l'étang de Berre ügyben -, hogy attól függetlenül vizsgálta meg a környezetvédelmi tárgyú vegyes egyezmény rendelkezésének közvetlen hatályát, hogy elvégezte volna az adott szabályozási tárgyban a közösségi jogalkotási jogkör előzetes kimerítésének vizsgálatát. ${ }^{33}$

Változatlanul kérdéses, hogyan követelheti meg a kiterjesztő jogértelmezést az EUB a tagállami bíróságoktól, ha a rendelkezés követelményeit azok közvetlen

30 A Tanács 2005/370/EK határozatának melléklete szerint „[a]z Európai Közösség különösen hangsúlyozza, hogy a hatályos jogi eszközök nem szabályozzák teljeskörüen az egyezmény 9. cikkének (3) bekezdésében meghatározott kötelezettségek végrehajtását, amennyiben magánszemélyek vagy a 2. cikk (2) bekezdésének d) pontjában szabályozott európai közösségi intézményektöl eltérő hatóságok intézkedéseik és mulasztásaik miatti felelősségre vonására szolgáló közigazgatási és igazságügyi eljárásokra vonatkoznak, következésképpen a tagállamok felelősek ezen kötelezettségek teljesitéséért az egyezménynek az Európai Közösség általi jóváhagyása időpontjában, és felelösek maradnak mindaddig, amíg a Közösség, az EKSzerződés alapján meglévő hatáskörét gyakorolva, el nem fogad közösségi jogszabályokat azon kötelezettségek teljesitésének szabályozásáról."

31 Bővebben lásd Scнink, Alexander: Der slowakische Braunbär und der deutsche Verwaltungsprozess. Die öffentliche Verwaltung, 16/2012, 622-631, 625-626; ECKEs, Christina: Environmental Policy „Outside-In.” How the EU's Engagement with International Environmental Law Curtails National Autonomy, EU Law qua Global Governance Law. German Law Journal, 2012/11, 1151-1176, 1168. Walter ugyanakkor kifejezetten az Aarhusi Egyezményt tekintette korábban olyan példának, amelyben a szükebb értelemben vett anyagi jogi és eljárásjogi rendelkezések már nem választhatóak el egymástól. WALTER, Christian: Internationalisierung des deutschen und Europäischen Verwaltungsverfahrens- und Verwaltungsprozessrechts - am Beispiel der Aarhus Konvention. Europarecht, 2005/3, 316.

32 Sharpston fötanácsnok indítványa, C-240/09., EU:C:2010:436, 70. pont.

33 A C-213/03. Syndicat professionnel coordination des pêcheurs de l'étang de Berre et de la région kontra Électricité de France (EDF) ügyben hozott 2004. július 15-i ítélet (ECLI:EU:C:2004:464) 39-48. pontjai. 
hatályának megállapításához ő maga túlzottan absztraktnak tartotta. Ebben a tekintetben megfontolandó felvetés, hogy a túlzottan absztrakt megfogalmazás, mint a közvetlen hatályú alkalmazás akadálya, hasonlóképpen ellenérvként szolgál az egyezménykonform bírói jogértelmezéssel szemben is. ${ }^{34}$

A közvetett hatály szerinti konform jogértelmezés követelményére mégis egyértelmüen reagált több tagállam gyakorlata. Igaz, csak bizonyos tagállamokban követték a kiterjesztő jellegű bírói jogértelmezést. A német Szövetségi Közigazgatási Bíróság 2013-ban már elismerte a civil szervezeti fellépés lehetőségét az irányelvi célkitűzések kiterjesztő értelmezésével egy levegőtisztaság-védelmi ügyben, többek között a szlovák barnamedvék ügyében hozott ítélet irányelvkonform jogértelmezése alapján. ${ }^{35}$ A Cseh Köztársaság Legfelsőbb Közigazgatási Bírósága 2010-ben is már ezen EUB-ítéletre hivatkozva bírálta felül a bírói gyakorlat addigi, a fellépési kereteket megszorító álláspontját. ${ }^{36}$ Az osztrák Szövetségi Közigazgatási Bíróság 2012-ben ugyanakkor elutasította a szlovák barnamedvék ügyében hozott ítélet irányelvkonform jogértelmezése alapján az Aarhusi Egyezmény 9. cikk (3) bekezdésének szellemében való kiterjesztő felfogású ítélkezés meghonosítását. ${ }^{37}$

\subsection{A szlovák szarvasok (LZ II) ügyben hozott ítélet}

\subsubsection{Az itéleti tényállás}

A második ügy alapjául ugyanazon szlovák erdővédelmi egyesület kérelme szolgált. Ez arra irányult, hogy ismerjék el ügyféli minőségét abban a közigazgatási eljárásban, amely egy védett területen található szarvasrezervátum bővítése céljából indult. Bővebben is érdemes ismertetni az ügy részleteit, mivel ebben a tekintetben a két előzetes döntéshozatali eljárás összekapcsolódott. Emellett az ügy részletei tágabb értelemben rávilágítanak a tagállami eljárási jog és az uniós jog összeütközése kapcsán tett feloldási kísérletekre a tagállami bíróságok részéről, illetve következtetni engednek az egyes bírói fórumoknak a problémához való hozzáállására is.

2008 végén érdekeltként a hatósághoz fordult az egyesület, amelynek meg is küldték a szóbeli eljárás jegyzőkönyvét, valamint a kért engedély megadásáról szóló határozat előkészítő dokumentumait. Az egyesület sikertelenül kérte a hatósági eljárás felfüggesztését, emellett pedig a másodfokon eljáró regionális körzeti hatóság is elutasította az ügyfélként való elismerés iránti kérelmét. ${ }^{38}$ Mindeközben pedig a körzeti hatóság megadta a vadrezervátum bővítésére az engedélyt. Az egyesület, hivatkozva az Aarhusi Egyezmény 9. cikk (3) bekezdésére, a regionális bírósághoz fordult, amely az EUB előtt akkor még folyamatban lévő szlovák barnamedvék ügy

34 JANS, Jan H.: Who is the Referee? Access to Justice in a Globalised Legal Order: A Case Analysis of ECJ Judgment C-240/09. Lesoochranárske Zoskupenie of 8 March 2011 (May 7, 2011). Review of European Administrative Law, 2011/1, 98-99.

35 A német Szövetségi Közigazgatási Bíróság 2013. szeptember 5-i, 7 C 21.12 sz. ítélete.

36 A Cseh Köztársaság Legfelsőbb Közigazgatási Bíróságának 2010. október 13-i, no. 6 Ao 5/2010. sz. ítélete.

37 Az osztrák Szövetségi Közigazgatási Bíróság 2012. április 27-i, 2009/02/0239. sz. ítélete.

38 C-243/15. sz., szlovák szarvasok ügyben hozott ítélet, 23. pont. 
befejezéséig felfüggesztette a saját eljárását. 2011-es döntésével a regionális bíróság különösen a szlovák barnamedvék ügyben hozott EUB-ítélet alapján megsemmisítette az alapügy tárgyát képező határozatokat.

Szlovákia Legfelsőbb Bírósága azonban hatályon kívül helyezte a regionális bíróság említett határozatát, és az ügyet visszautalta a regionális bíróság elé. A döntés indokolása hivatkozott a szlovák perjogi szabályokra, amelyek szerint az ügyféli minőséget megtagadó döntés felülvizsgálata már kizárt, miután az eljárás jogerősen érdemben lezárult. Emellett kiemelte a legföbb bírói fórum az érdekelt értesítési kötelezettségét a perjogi szabályok szerint, amelyek lehetővé teszik az ügyféli minöség megtagadásának vitatását, de pusztán hároméves törvényi határidőn belül. ${ }^{39}$

A regionális bíróság 2012. szeptember 12-i határozatával másodszor is megsemmisítette az alapügy tárgyát képező határozatokat, amelyet a Legfelsőbb Bíróság ismét hatályon kívül helyezett, lényegében a korábbi határozatában foglaltakkal azonos indokok alapján. ${ }^{40}$ Végül a regionális bíróság 2013. november 23-i határozatával azzal utasította el az egyesület ügyféli minőség elismerése iránti kérelmét, és nyilvánította ki a keresetindításra vonatkozó külön értesítés szükségtelenségét, hogy időközben a perjogi szabályokban lefektetett hároméves határidő letelt. ${ }^{41}$ Az előzetes döntéshozatali kérelemben az Alapjogi Charta 47. cikke szerinti hatékony jogorvoslathoz és tisztességes eljáráshoz való jogra - a kapcsolódó uniós, egyben aarhusi rendelkezésekre és a szlovák barnamedvék ügyében hozott ítéletre is tekintettel - Szlovákia Legfelsőbb Bírósága tette fel a kérdést, hogy e követelményekkel összeegyeztethető-e az ügyféli jogállás megtagadása miatti külön keresetindítás tagállami elöírása. ${ }^{42}$

\subsubsection{Az ítéleti érvelés}

Az ítélet érvelésének kiindulópontja, hogy az élőhelyvédelmi irányelv jogi kötőerővel bíró célkitüzései megkövetelik - a lakosság véleményének kikérése és a korai részvétel biztosítása mellett -, hogy az egyesület részt vehessen az olyan terv vagy projekt engedélyezésére vonatkozó döntéshozatali eljárásban, amely jelentős hatással lehet a környezetre. ${ }^{43} \mathrm{~A}$ tagállami eljárási autonómia ebben a tekintetben az ítélet szerint csak a nyilvánosság részvételi módjainak meghatározását öleli fel, ám az egyesülethez hasonló környezetvédelmi szervezeteknek a részvételi jogát biztosítaniuk kell a tagállamoknak. ${ }^{44}$ Bár jelen ügyben a részvételt biztosították az egyesület érdekeltként való bevonásával is, ám továbbra is kérdéses, hogy a részvétel milyen eljárási (és jogorvoslati) jogokat foglal magában.

A Charta hatékony jogorvoslatra vonatkozó 47 . cikkét és az alkalmazásának tárgyi hatályát szabályozó 51 . cikkét, valamint az uniós aarhusi rendelkezéseket együttesen értelmezve jutott arra a következtetésre az EUB, hogy jelen ügyben az uniós

${ }^{39}$ C-243/15. sz., szlovák szarvasok ügyben hozott ítélet, 29. pont.

40 C-243/15. sz., szlovák szarvasok ügyben hozott ítélet, 32. pont.

41 C-243/15. sz., szlovák szarvasok ügyben hozott ítélet, 33. pont.

42 C-243/15. sz., szlovák szarvasok ügyben hozott ítélet, 34-38. pontok.

43 C-243/15. sz., szlovák szarvasok ügyben hozott ítélet, 42-49. pontok.

${ }^{44}$ C-243/15. sz., szlovák szarvasok ügyben hozott ítélet, 48. pont. 
jog tagállami végrehajtása valósul meg, amelynek vizsgálatára az EUB hatáskörrel rendelkezik. ${ }^{45} \mathrm{Az}$ EUB, hivatkozva a fötanácsnoki indítványra is, az élőhelyvédelmi irányelv 6. cikkének (3) bekezdése keretében hozott határozatokat az Egyezmény 9. cikk (2) bekezdése alá tartozó határozatoknak tekintette. ${ }^{46} \mathrm{Ez}$ az élőhelyvédelmi rendelkezés alapvetően a tagállami hatóságok kötelezettségét rögzíti, hogy - a hatásvizsgálat szükségtelensége esetén is - a tevékenység bármiféle engedélyezését megelőzően értékeljék, hogy a tevékenység az adott ügy körülményei között, jelentős hatással lehet-e a környezetre, illetve kérjék ki az érintett lakosság véleményét. Kérdés, hogy mennyiben lehetséges az eljárási kötelezettséget kiterjesztően, az egyesület szempontjából jogosultságként értelmezni.

A kiterjesztő hozzáállás egyértelműen tetten érhető az EUB érvelésének egészén, amely idézte a legtöbb saját korábbi, aarhusi vonatkozású megállapítását. Így felidézte a széles körủ igazságszolgáltatáshoz való jog biztosításának kötelezettségét, amely korlátozza a tagállamok mérlegelési körét a jogorvoslat módjának meghatározásakor. ${ }^{47} \mathrm{E}$ szervezetek számára (amilyen az egyesület is) lehetővé kell tenni, hogy a bíróság elött hivatkozni tudjanak az uniós környezetvédelmi jogot végrehajtó nemzeti jogi szabályokra, valamint a közvetlenül hatályos uniós környezetvédelmi jogi szabályokra. ${ }^{48} \mathrm{Az}$ élöhelyvédelmi irányelv 6 . cikk (3) bekezdésének szerepelnie kell az olyan jogok (hatósági eljárási kötelezettségek) sorában, amelyekre egy ilyen egyesület hivatkozhat. ${ }^{49}$ Végül az egyesület vitathatja a határozatot a vizsgálat elmaradása mellett annak szabálytalan volta okán is..$^{50}$ Így az EUB áthidalta a 9. cikk (3) bekezdése szerinti követelmények uniós jogalkalmazó általi átvételének elmaradását, és a részvétel visszásságai mellett biztosítja a tartalmi követelmények vitathatóságát is az olyan környezetvédelmi szervezetek számára, mint amilyen az ügyben szereplö egyesület.

Az ítéletben az EUB a Charta 47. cikke és az Egyezmény „elégséges és hatékony" jogorvoslati követelménye mentén vezette le a tagállami bíró értelmezésének kereteit és korlátait. ${ }^{51}$ Ellentétben a fötanácsnoki indítvánnyal, nem folytatott le az egyenértékűség és a tényleges érvényesülés elveire vonatkozó részletes tesztet. ${ }^{52}$ Ehelyett megállapította, hogy az egyesület érdekelti pozíciója nem feleltethető meg az ügyféli minőségnek, még ha valamifajta részvételi jogokat érdekeltként

45 C-243/15. sz., szlovák szarvasok ügyben hozott ítélet, 50-53. pontok.

46 C-243/15. sz., szlovák szarvasok ügyben hozott ítélet, 57. pont.

47 C-243/15. sz., szlovák szarvasok ügyben hozott ítélet, 58. pont; C-570/13. sz., Karoline Gruber kontra Unabhängiger Verwaltungssenat für Kärnten és társai ügyben 2015. április 16-i ítélet (ECLI:EU:C:2015:231), 39. pont.

48 C-243/15. sz., szlovák szarvasok ügyben hozott ítélet, 59. pont; C-137/14. sz., Bizottság kontra Németország ügyben 2015. október 15-i ítélet (ECLI:EU:C:2015:683), 92. pont.

49 C-243/15. sz., szlovák szarvasok ügyben hozott ítélet, 60. pont; C-115/09. sz., Bund für Umwelt und Naturschutz Deutschland, Landesverband Nordrhein-Westfalen eV kontra Bezirksregierung Arnsberg ügyben 2011. május 12-i ítélet (ECLI:EU:C:2011:289), 49. és 58. pontok.

50 C-243/15. sz., szlovák szarvasok ügyben hozott ítélet, 61. pont; Gemeinde Altrip és társai ítélet, C-72/12., EU:C:2013:712, 37. pont.

51 C-243/15. sz., szlovák szarvasok ügyben hozott ítélet, 61-65. pontok.

52 Kokott fötanácsnok indítványa, C-243/15., EU:C:2016:491, 98-99. pontok. 
is gyakorolhatott. ${ }^{53} \mathrm{~A}$ kapcsolódó fötanácsnoki indítvány az ügy egyes tényeit és konkrét körülményeit bár figyelembe vette, de a tagállami eljárási autonómiát tiszteletben tartva jutott arra a következtetésre, hogy önmagában az ügyféli minőség megtagadása és a hároméves jogvesztő határidő nem ütközik a kapcsolódó uniós követelményekbe. ${ }^{54}$ Azonban ettöl eltérö álláspontra helyezkedett az EUB, amely sokkal határozottabban vette figyelembe az ügy egyedi körülményeit. Így kiemelte azt, hogy a tagállami jog szerint az ügyféli minőségét megtagadó közigazgatási határozattal szemben benyújtott keresetet nem kellett szükségszerủen elbírálni az engedélyezési eljárás tartama alatt, és azt hivatalból elutasították, amint a kért engedélyt megadták. ${ }^{55}$ Végül kitért érvelésében az előterjesztő bíróság álláspontjára is az EUB, miszerint fennáll annak a veszélye is, hogy az élöhelyvédelmi irányelv céljai semmiképpen nem valósulnak meg, ha ügyfélként az eljárásban csak az engedély kérelmezője vesz részt. ${ }^{56}$

\subsubsection{Az itéleti érvelés kritikája}

Az EUB aarhusi vonatkozású ítéleteinek száma már olyan jelentős, hogy esetjogi hivatkozások lehetővé tették, hogy a szervezeti fellépés kereteit már tágan értelmezze az EUB. Ennek keretében pedig már az Egyezmény 9. cikk (2) bekezdés alapján is lehetséges volt annak megállapítása, hogy a környezetvédelmi tervek és projektek tartalmi követelményeit is vitathatják a környezetvédelmi szervezetek, áttételesen a részvételi követelmények megsértése miatt is. Ahogyan szakirodalmi állásfoglalások jelzik, az aktivista megközelítés abban is megmutatkozik, hogy az EUB az Egyezmény egyes konkrét rendelkezései és saját esetjogi megállapításai alapján ítéli meg az uniós követelményeknek való megfelelést - holott azok átültetése egyes jelzett esetekben kérdéses vagy éppen az adott elképzelés nem feltétlenül hatásvizsgálat-köteles. ${ }^{57}$

A fötanácsnoki indítvány is elismerte, hogy vannak arra utaló jelek, hogy az egyesület számára rendkívül nehézzé tették a jogérvényesítést. ${ }^{58}$ Ugyanakkor a tagállami jogorvoslati rendszer egyes elemeit (jogvédelmi szabályozás, alapeljárás menete, jogvesztő határidő) megvizsgálva nem állapította meg azok összeegyeztethetetlenségét az uniós követelményekkel. Ellentétben az EUB ítéletével, amely kiterjesztő jogértelmezést követett, egyrészt az eddigi esetjogra, másrészt kifejezetten az ügy körülményeire, valamint a szervezet helyzetére is figyelemmel. A szakirodalmi értékelések is utaltak már arra a jogvédelmi jellegzetességre, hogy a jogorvoslati jogok gyakorolhatósága a hatósági eljárásban a szubjektív (saját jog, jogos érdek) érintettségén alapulhat egyes tagállamokban. Ezzel szemben az objektív (a köz egésze vagy adott közösség érdekében való) fellépés, amelyet többek között az egyesüle-

53 C-243/15. sz., szlovák szarvasok ügyben hozott ítélet, 67-68. pontok.

54 Kokott fötanácsnok indítványa, C-243/15., EU:C:2016:491, 122. pont.

55 C-243/15. sz., szlovák szarvasok ügyben hozott ítélet, 68. pont.

56 C-243/15. sz., szlovák szarvasok ügyben hozott ítélet, 70. pont.

57 VAN WolfEREN, Matthijs: Case C-243/15 Lesoochranárske zoskupenie VLK kontra Obvodný úrad Trenčín. Journal for European Environmental \& Planning Law, 2017/1, 146-147.

58 Kokott főtanácsnok indítványa, C-243/15., EU:C:2016:491, 117. pont. 
tek megvalósítanak, az engedélyezési eljárásokban sokszor a kérelmet előterjesztőket egyedüli ügyfélként elismerő jogrendszerek jogvédelmi hiányosságaira reagál. ${ }^{59}$ Ezen érv egyértelmúen befolyásolta az EUB álláspontját, hiszen már az idézett aarhusi kötődésú esetjogi megállapítások is arra engednek következtetni, hogy az EUB sokkal tágabban értelmezi a kapcsolódó uniós követelményeket.

Bár nem alkalmazott részletes egyenértéküségi és tényleges érvényesülésre utaló tesztet az EUB, ám egyértelműen jelezte az egyenértékúség hiányát az egyesület érdekelti pozíciója miatt, amely kizárta fellépését az ügyféli minőség hiánya okán.

Említésre érdemes mozzanata volt az ügynek, hogy az előzetes döntéshozatali eljárás kezdeményezésére csak azt követően került sor, hogy Szlovákia legföbb bírói fóruma több alkalommal is hatályon kívül helyezte a regionális bíróság döntését. Az előzetes döntéshozatali eljárások kapcsán egyes szerzők korábban már megpróbáltak azt illetően következtetéseket levonni, hogy az alsóbb fokú bíróságok nagyobb mértékben élnek a lehetőséggel. (Eszerint ők akkor élnek a kezdeményezéssel, ha saját jogi álláspontjukat kívánják alátámasztani, míg a felső bíróságok legfeljebb akkor, ha a belső jogi tradícióktól kívánnak eltérni. ${ }^{60}$ Bizonyos szempontból jelen ügy is alátámasztja ezt a feltételezést, bár a számadatok tükrében az előzetes döntéshozatali eljárások kezdeményezésénél az alsóbb fokú bíróságok vannak többségben (vagy legalábbis majdnem azonos szinten) Szlovákia, Magyarország és még Csehország esetében is. ${ }^{61}$

\section{Következtetések}

Az EUB aarhusi kötődésű ítélkezési gyakorlata alapján a tagállamok eljárási autonómiája egyre inkább relativizálódik. Ennek egyértelmú oka az EUB gyakorlata és aktivista hozzáállása, amellyel az Egyezményt az uniós jog integráns részének ismeri el. ${ }^{62}$ Egyértelmú az is, hogy az aarhusi követelmények tagállami alkalmazása a jogalkalmazók számára kihívást teremtett. A normahierarchia szempontjából ugyanis három szinten jelennek meg a különböző követelmények: a nemzetközi egyezmény, az uniós irányelvek és a tagállami kihirdetési és átültetési aktusok formájában. Az elemzett ügyek esetében megmutatkozik a tagállami jogalkalmazó dilemmája, aki az absztrakt és további feltételtől függő követelmények konkretizálására, valamint azok tagállami bíróság előtti kikényszeríthetőségének biztosítására köteles.

Az EUB esetjogi megállapításai ugyanakkor adtak viszonyítási pontokat a tagállami bírói gyakorlatnak, de éppen az aarhusi tárgyú ítéletei alapján az EUB kevésbé

59 A beruházó, illetve környezethasználó helyzetét érintő német dogmatikai álláspontot illetően lásd bővebben Murswiek, Dietrich: Ausgewählte Probleme des allgemeinen Umweltrechts. Vorsorgeprinzip, Subjektivierungstendenzen am Beispiel der UVP, Verbandsklage. Die Verwaltung, 2005/2, 243-279.

60 Alter, Karen J.: The European Court's Political Power. West European Politics, 1996/3, 458-487. ConAnt, Lisa: Compliance and What EU Member States Make of It. In: Cremona, Marise (ed.): Compliance and the Enforcement of EU Law. Oxford University Press, Oxford, 2012, 10.

61 Soмmsıcн Réka: Előzetes döntéshozatali eljárások a számok tükrében: a 2004-ben csatlakozott országok bíróságai által kezdeményezett eljárások 10 évvel a csatlakozás után. Európai Jog, 2015/2, 4.

62 VAN Wolferen: i. m., 149. 
volt tekintettel a tagállamok eljárási szabályozására és autonómiájára. Ennek révén pedig egyre inkább kiterjeszti az eljárási jogosultságok kapcsán kialakított követelményrendszerét. Ez a fajta kiterjesztő gyakorlat a tagállamok közötti és az egyes ágazatokon túlmutató jelentőséggel is bírhat.

Nehéz megítélni, mennyiben hat majd ki más tagállamokra a szlovák szarvasok ügyében hozott ítélet, hiszen érvelésében az EUB kifejezetten kitért az ügy egyedi körülményeire is. Ám a szlovák barnamedvék ügyében hozott ítélet más tagállamok bírói fórumai elött is egyértelműen megjelent hivatkozási alapként. Álláspontom szerint a szlovák szarvasok ügyében hozott ítélet az egyedi szabályozásra és perjogi körülményekre tett utalások miatt kevésbé válik más tagállamok bírói fórumai által idézetté, de mégis befolyásolhatja az ítélkezést, ha a konkrét egyezményi követelményeket ezen döntés nyomán a bírói fórumok egyre inkább (ténylegesen) az uniós jog részeként fogják fel.

Elgondolkodtató az is, hogy egyáltalán maradt-e a környezetvédelemnek olyan részterülete, ahol a tagállam az uniós követelményektöl függetlenül alkothatna jogot. ${ }^{63}$ Emellett az elemzett döntések alapvető fontosságú tagállami eljárásjogi vagy perjogi szabályoknak az uniós joggal való összeegyeztethetetlenségét állapították meg. Így a tagállami általános eljárási szabályozásra is szükségszerüen egyre inkább kihat az EUB tevékenysége, ami idővel egyre inkább erősödhet a más ágazatokban megszülető esetjogi megállapítások révén. A hatékony jogvédelem biztosításának követelményére az EUB például egy adatvédelmi tárgyú ügyben, de a szlovák szarvasok ügyében hozott ítéletet idézve utalt vissza. ${ }^{64}$

Ráadásul, ahogyan arra röviden utaltam, az Aarhusi Egyezmény képes rávilágítani a többszintủ európai jogvédelmi rendszer jelenleg is fennálló felemás, ebben a tekintetben hiányos rendszerére. Nem képezte jelen cikk tárgyát az uniós bíróságok előtti fellépés vizsgálata, de a tagállami szintre vonatkozó aktivista hozzáállás nem jelenik meg az EUB részéröl a saját maga előtti egyéni fellépés (az igazságszolgáltatáshoz való hozzáférés) kapcsán. Az Aarhusi Jogkövetési Bizottság, amely részes félként az EU Egyezménynek való megfelelését is vizsgálja, így állapította meg, hogy az uniós bíróságok előtti felülvizsgálati lehetőségek túl szükre szabottak a 9. cikk elvárásaihoz képest. ${ }^{65}$ Ugyanakkor az EUB saját érvelése szerint is „kétségtelenül érdek füződik ahhoz, hogy a jövőbeni eltérő értelmezések elkerülése végett,

63 BerkemAnN, Jörg: Die unionsrechtliche Umweltverbandsklage des EuGH - Der deutsche Gesetzgeber ist belehrt ıso nicht ‘ und in Bedrängnis. Deutsches Verwaltungsblatt, 2011/20, 1260-62. Ugyanakkor az EUB gyakorlatában arra is találunk példát, amikor az aarhusi követelmények csak a szűk értelemben vett környezeti ügyekben nyertek alkalmazást. VÁRADI Ágnes: Az Aarhusi Egyezmény értelmezésének egyes kérdései az Európai Unió Bíróságának gyakorlatában. Állam- és Jogtudomány, 2018/2, 101.

64 C-73/16. sz., Peter Puškár és a Finančné riaditel'stvo Slovenskej republiky, a Kriminálny úrad finančnej správy ügyben 2017. szeptember 27-i ítélet (ECLI:EU:C:2017:725) 57. pontja.

65 A Plaumann-teszt (semmisségi eljárásokban az egyéni keresetindítás feltétele máig az esetjogi alapon kidolgozott személyes és közvetlen érintettség) alkalmazásának vizsgálatával összefüggésben az Aarhusi Jogkövetési Bizottság megállapította, hogy annak környezeti ügyekre való alkalmazása, valamint a kapcsolódó megszorító jogértelmezés azzal is együtt járhat, hogy a nyilvánosság semelyik tagjának keresetindítási jogát nem ismeri el az EUB az előtte folyó eljárásokban. Ezt érvelésében kiegészítette azzal, hogy nem felel meg az Aarhusi Egyezmény 9. cikkében támasztott követelményeknek az előzetes döntéshozatali eljárás keretében biztosított felülvizsgálati lehetőség, valamint az semmiképpen sem szolgálhat hivatkozási alapul 
ha valamely rendelkezés mind a nemzeti jog, mind az uniós jog hatálya alá tartozó helyzetekre alkalmazandó lehet, akkor e rendelkezést egységesen értelmezzék, függetlenül azoktól a feltételektöl, amelyek között e rendelkezés alkalmazandó”. ${ }^{66}$ Az okfejtés alapján a kiterjesztő jogértelmezés érvényesítése elvárható az aarhusi követelmények uniós szintű érvényesítésekor is, ami utóbb feloldhatná a felemás jogvédelem ellentmondásosságát.

Összességében a két évtizedes múltra visszatekintő Aarhusi Egyezmény mára kiemelkedő jelentőségre tett szert, és alapvető eljárásjogi, perjogi kérdésekben is alakítja az európai jogfejlődést, a környezeti ügyeken is túlmutató, általános jelleggel.

\section{Abstract}

The Aarhus Convention guarantees access to information, public participation and access to justice in environmental matters. The Convention as a so-called mixed-agreement has been ratified by the EU as well as by its Member States. The Convention-related case-law of the Court of Justice of the EU (CJEU) especially relating to Slovakia (see, C-240/09 - Slovak bears, C-243/15 - Slovak deers) shows that the Court has broadened the locus standi of NGOs before national courts using them in order to facilitate the enforcement of EU law. The activism followed by the Court in these judgements could be considered as environmental-specific expression of the objective of broader law enforcement before national courts. However it depends on national courts whether this kind of CJEU judgments could acquire cross-border relevance by their application of national judges.

az Európai Unió bírói fórumai előtti fellépés kizárásához (Aarhusi Jogkövetési Bizottság ACCC/C/2008/32 sz. jelentésének 86-90. pontjai).

66 Bernd Giloy-ítélet, C-130/95., EU:C:1997:372, 28. pont; Hermès International ítélet, C-53/96., EU:C:1998:292, 32. pont. 